\title{
Factors affecting prevailing population levels of Brevipalpus yothersi (Acari: Tenuipalpidae) in citrus areas affected by citrus leprosis in the State of Sao Paulo, Brazil
}

\author{
I. Amaral ${ }^{1}$ (D) - G. J. de Moraes ${ }^{1}$ - C. C. Melville ${ }^{1}$ D. J. Andrade ${ }^{1}$
}

Received: 23 October 2017 / Accepted: 15 February 2018 / Published online: 7 March 2018

(C) Springer International Publishing AG, part of Springer Nature 2018

\begin{abstract}
Brevipalpus yothersi Baker (Acari: Tenuipalpidae) was recently confirmed as one of the main vectors of citrus leprosis. Knowledge about this mite's biology is essential to understand its population dynamics, in order to solve management issues in citrus orchards and explain why citrus leprosis is more severe in some regions. This paper aimed to study biological factors affecting prevailing population levels of $B$. yothersi and incidence of citrus leprosis. Mites were sampled from orchards in the south, north and northwestern regions of São Paulo State, Brazil. We assessed duration of the developmental stages, oviposition, incubation period, egg viability, longevity, net reproductive rate $\left(\mathrm{R}_{\mathrm{o}}\right)$, mean generation time $(T)$, intrinsic rate of increase $\left(r_{m}\right)$ and finite rate of increase $(\lambda)$. There were small differences in parameter values between the three populations. Our results indicated that the various measures adopted in the control of the three populations did not lead to major biological differences between populations for the evaluated parameters.
\end{abstract}

Keywords Citrus sinensis $\cdot$ Brevipalpus phoenicis $\cdot$ Brevipalpus species complex $\cdot$ Flat mites $\cdot$ Biological parameters

\section{Introduction}

Until recently, Brevipalpus phoenicis (Geijskes) (Acari: Tenuipalpidae) was considered the only vector of citrus leprosis virus in Brazil, whereas Brevipalpus californicus (Banks) and Brevipalpus obovatus Donnadieu were considered the vector of that pathogen in the USA and Argentina, respectively (Bastianel et al. 2010). However, the examination of a large number of specimens from different countries previously determined as B. phoenicis led Beard et al. (2015) to conclude that they actually corresponded to a species complex,

I. Amaral

ingridamaral88@hotmail.com

1 School of Agricultural and Veterinary Sciences (UNESP/FCAV), UNESP - São Paulo

State University, Via de Acesso Prof. Paulo Donato Castellane, s/n ${ }^{\circ}$, Jaboticabal,

São Paulo State CEP 14884-900, Brazil 
which included Brevipalpus yothersi Baker. Based on that study, Mineiro et al. (2015) concluded that the predominant species in citrus orchards of the Brazilian state of São Paulo was B. yothersi.

To the best of our knowledge, no previous study referring to the biology of B. yothersi has been published, although at least some of the previous biological studies referring to $B$. phoenicis could in fact correspond to $B$. yothersi. Basic studies on the biology of this mite vector are fundamental to establish measures for its appropriate control and reduction of the incidence of the citrus leprosis virus.

The greater genetic variability of Brazilian populations of $B$. yothersi in comparison with populations collected elsewhere suggests this species to have originated in Brazil (Salinas-Vargas et al. 2016). One of the factors associated with greater genetic variability could be the management adopted in citrus. Alternating acaricides used in the integrated pest management orchards could be responsible for differences in population genetics (Pascual-Ruiz et al. 2014). These authors conclude that reduced pesticide application leads to lower genetic diversity (Pascual-Ruiz et al. 2014) and a lower adaptive cost.

The major citrus leprosis viruses ( $\mathrm{CiLV}-\mathrm{C},-\mathrm{C} 2$ and $-\mathrm{N}$ ) were detected by conventional and reverse strand specific RT-PCR in B. yothersi by Roy et al. (2015), confirming this species as one of the major vectors of the disease. Citrus leprosis affects all citrus-producing regions in Brazil, being more severe in the northern and northwestern regions of São Paulo State. This difference was attributed by Bassanezi et al. (2002) to be due to differences in prevailing climatic factors. In the orchards located in the southern region of the state, the incidence of citrus leprosis is reduced, which leads growers to apply acaricides less often to control Brevipalpus mites. This can generate biological differences between populations, including the efficiency of virus transmission.

The hypothesis of the present work was that populations of B. yothersi of important citrus regions have different biological characteristics, given the different control measures to which they have been subjected. If this is proven, it may help to explain the different degree of importance of citrus leprosis among regions. Determination of the biology of populations of $B$. yothersi in each region is essential to understand their population dynamics in the field, improving monitoring techniques and strategies for the control of the mite and citrus leprosis.

Thus, the aim of this study was to determine the biology and the fertility life-table parameters of B. yothersi populations from three important citrus-producing regions of São Paulo State, to relate the possible differences with the different levels of occurrence of the mite and citrus leprosis in each region.

\section{Materials and methods}

\section{Sampling}

Mites used in this study were collected from commercial orchards. The first mite population was collected on 29 August 2014 from a 9-year-old orchard of 'Pera' sweet orange grafted on 'Cleopatra' mandarin, at Agroterenas farm, municipality of Santa Cruz do Rio Pardo, in southern São Paulo State (22 48'52.57"S, 49¹9'35.30"W; 573 m above sea level). The second population was collected on 12 November 2014 from a 5-year-old orchard of 'Valencia' sweet orange grafted on 'Sunki' tangerine, at Vila Rica farm, municipality of Barretos, in northern São Paulo (20³7'29.78"S, 4850'12.73"W; 528 m a.s.1.). The third 
population was collected on 7 November 2014 from a 13-year-old orchard of 'Green Lime' grafted on 'Rangpur lime', at Costa and Melo farm, municipality of Jales, in northwestern São Paulo (2006'03.99"S, 50³6'59.59"W; $436 \mathrm{~m}$ a.s.1.). The history of pesticide applications at the collection areas in the previous year is presented in Table 1. Average climatic parameters in the collection sites were: Santa Cruz do Rio Pardo, $22.6{ }^{\circ} \mathrm{C}, 71 \% \mathrm{RH}$ and annual rainfall of $1475 \mathrm{~mm}$; Barretos, $24.8{ }^{\circ} \mathrm{C}, 62 \% \mathrm{RH}, 1254 \mathrm{~mm}$ annual rainfall; Jales, $24.3{ }^{\circ} \mathrm{C}, 66 \% \mathrm{RH}, 1222 \mathrm{~mm}$ annual rainfall (averages for 1985-2015; INMET 2015).

Infested fruits were collected and transported to a laboratory for the establishment of stock colonies on unsprayed 'Natal' sweet oranges, which were washed with tap water and partially covered with wax, leaving a small arena (about $10 \mathrm{~cm}^{2}$ ) uncovered, for colonization by the mites. Irregularities on the surface of these arenas were setup using a mixture of sand, gypsum, wheat flour and water at a ratio of 4:1:1:3, to simulate irregularities of fruit skin, favored by the mite (Salinas-Vargas et al. 2016). The edges of the arenas were smeared to prevent mites from escaping. Colonies were maintained in a climatic chamber at $23 \pm 1{ }^{\circ} \mathrm{C}, 60 \pm 10 \% \mathrm{RH}$ and $14 \mathrm{~h}$ daily photoperiod, replacing the fruits as needed.

\section{Mite identification}

Adult females were taken randomly from each colony and mounted on microscope slides containing Hoyer's medium for examination under a differential interference contrast microscope. Identification was based on Beard et al. (2015).

\section{Life cycle}

For determination of the biological parameters, experimental units were setup on fruits harvested from the same orchard as the fruits used for the stock colonies, and the experimental units $\left(2.5 \mathrm{~cm}^{2}\right)$ were similar to the units used for the stock colonies. One adult female was transferred to each unit. $24 \mathrm{~h}$ later, the females and excess eggs were removed, leaving only one egg per unit. The study was conducted between June and August 2015, under the same conditions at which the colonies were maintained, with 50 replicates, each corresponding

Table 1 History of pesticide applications at the collection areas, in the year preceding collection of the mites in the northern, northwestern and southern region of Sao Paolo state, Brazil (2013-2014)

\begin{tabular}{|c|c|c|c|c|c|c|}
\hline \multirow[t]{2}{*}{ Class } & \multirow[t]{2}{*}{ Pesticide } & \multirow[t]{2}{*}{ Active ingredient } & \multirow[t]{2}{*}{ Chemical group } & \multicolumn{3}{|c|}{ Number of applications } \\
\hline & & & & North & Northwest & South \\
\hline \multirow[t]{5}{*}{ Acaricide } & Okay $^{\mathrm{a}}$ & Cyflumetofen & Benzoilacetonitrile & - & - & 1 \\
\hline & Envidor $^{\mathrm{a}}$ & Spirodiclofen & Ketoenol & 1 & 1 & - \\
\hline & Torque $^{\mathrm{a}}$ & Fenbutatin & Organotin & - & 1 & - \\
\hline & Dicofol $^{\mathrm{a}}$ & Dicofol & Organochlorine & 1 & - & - \\
\hline & Savey $^{\mathrm{a}}$ & Hexythiazox & $\begin{array}{l}\text { Thiazolidine } \\
\text { carboxamide }\end{array}$ & 1 & - & - \\
\hline \multirow{4}{*}{$\begin{array}{l}\text { Acaricide/insec- } \\
\text { ticide }\end{array}$} & Kraft $36 \mathrm{CE}$ & Abamectin & Avermectin & - & - & 6 \\
\hline & Micromite 240 SC & Diflubenzuron & Benzoylurea & - & - & 1 \\
\hline & Talstar $100 \mathrm{CE}$ & Bifenthrin & Pyrethroid & - & 2 & 4 \\
\hline & Abamex & Abamectin & Avermectin & 26 & 3 & - \\
\hline
\end{tabular}

${ }^{\text {a } E x c l u s i v e ~ a p p l i c a t i o n ~ f o r ~ t h e ~ c o n t r o l ~ o f ~ c i t r u s ~ l e p r o s i s ~ m i t e ~}$ 
to one mite. The experiment was initiated about 8 months after the establishment of the stock colonies (about 11 generations) in order to avoid pre-imaginal conditioning.

Units were examined daily at 8:00 AM and 4:00 PM, to determine duration of each stage, oviposition and survivorship. Data were tested for normality and homogeneity of variance and subsequently the averages were compared using Tukey's test $(\alpha=0.05)$.

\section{Fertility life tables}

A fertility life table was constructed for each population, based on all tested mites (including those that died during development), as proposed by Chi (1988). The original data for all individuals were analyzed according to the theoretical model proposed by Chi and Liu (1985), using the TWOSEXMS Chart program (Chi 2016). Parameters evaluated were agestage specific survival rate $\left(S_{\mathrm{xj}}\right)$, age-specific survivorship rate $\left(1_{\mathrm{x}}\right)$, age-specific fecundity $\left(\mathrm{m}_{\mathrm{x}}\right)$, age-stage specific survivorship expectancy $\left(\mathrm{e}_{\mathrm{xj}}\right)$, and age-stage specific reproduction values $\left(\mathrm{v}_{\mathrm{xj}}\right)$, as described by $\mathrm{Chi}$ and $\mathrm{Su}$ (2006). Intrinsic growth rate was calculated according to the method proposed by $\mathrm{Chi}$ and $\mathrm{Su}$ (2006).

The experiment was conducted as a fully randomized design. The mean and standard error of each biological and population parameter was estimated by the bootstrap method, following the procedure proposed by Huang and Chi (2012). Treatment means were compared by paired bootstrap test, based on the confidence interval of differences (Efron and Tibshirani 1993; Akkopru et al. 2015).

\section{Results}

Although significant differences were observed for most evaluated parameters (except for duration of post-oviposition), these were small, except for total duration of the life cycle (equivalent period from egg phase to death of mite) (Table 2). Differences between fecundity and viability were also small. As a consequence, differences between life-table parameters were small, despite their significance (Table 3). Adult longevity was slightly longer for the northwestern and shortest for the southern populations (Fig. 1).

Table 2 Mean ( \pm SE) biological parameters of Brevipalpus yothersi collected in the northern, northwestern and southern region of Sao Paolo state, Brazil, maintained at $23 \pm 1{ }^{\circ} \mathrm{C}, 60 \pm 10 \% \mathrm{RH}$ and $14 \mathrm{~h}$ of daily photoperiod

\begin{tabular}{lrrrrrl}
\hline Biological parameters & \multicolumn{1}{l}{ Region } & & $F_{2,144}$ & $P$ \\
\cline { 2 - 4 } & \multicolumn{1}{l}{ Northern } & \multicolumn{1}{c}{ Northwestern } & \multicolumn{1}{c}{ Southern } & & \\
\hline Immature phase (egg-adult) (days) & $24.0 \pm 0.1 \mathrm{a}$ & $23.4 \pm 0.1 \mathrm{~b}$ & $21.8 \pm 0.2 \mathrm{c}$ & 72.5 & $<0.01$ \\
Pre-oviposition (days) & $2.7 \pm 0.1 \mathrm{~b}$ & $3.5 \pm 0.1 \mathrm{a}$ & $3.4 \pm 0.2 \mathrm{a}$ & 11.0 & $<0.01$ \\
Oviposition (days) & $19.3 \pm 0.2 \mathrm{a}$ & $19.2 \pm 0.2 \mathrm{a}$ & $17.0 \pm 0.2 \mathrm{~b}$ & 29.0 & $<0.01$ \\
Post-oviposition (days) & $3.0 \pm 0.2 \mathrm{a}$ & $3.2 \pm 0.1 \mathrm{a}$ & $3.4 \pm 0.1 \mathrm{a}$ & 1.9 & $>0.05$ \\
Fecundity (nu. eggs/female) & $21.3 \pm 0.4 \mathrm{a}$ & $21.6 \pm 0.3 \mathrm{a}$ & $19.7 \pm 0.2 \mathrm{~b}$ & 12.6 & $<0.01$ \\
Viability (\%) & $97.4 \pm 0.6 \mathrm{~b}$ & $98.1 \pm 0.5 \mathrm{ab}$ & $99.4 \pm 0.2 \mathrm{a}$ & 4.1 & $<0.05$ \\
Longevity (days) & $24.9 \pm 0.2 \mathrm{~b}$ & $25.9 \pm 0.2 \mathrm{a}$ & $23.8 \pm 0.3 \mathrm{c}$ & 22.4 & $<0.01$ \\
Life cycle (days) & $48.9 \pm 0.2 \mathrm{a}$ & $49.3 \pm 0.2 \mathrm{a}$ & $45.5 \pm 0.3 \mathrm{~b}$ & 21.1 & $<0.01$ \\
\hline
\end{tabular}

Means within a row followed by the same letter do not differ significantly (Tukey's test: $P>0.05$ ) 
Table 3 Net reproductive rate $\left(R_{o}\right)$, duration of a generation $(T)$, intrinsic rate of increase $\left(r_{m}\right)$ and finite rate of increase $(\lambda)$ per female per day of Brevipalpus yothersi collected in the northern, northwestern and southern region of Sao Paolo state, Brazil

\begin{tabular}{lccl}
\hline $\begin{array}{l}\text { Biological } \\
\text { parameters }\end{array}$ & \multicolumn{2}{l}{ Regions } & \\
\cline { 2 - 4 } & North & Northwest & South \\
\hline$T$ & $17.17 \pm 1.26 \mathrm{~b}$ & $18.24 \pm 1.17 \mathrm{a}$ & $17.25 \pm 1.19 \mathrm{~b}$ \\
$R_{o}$ & $20.658 \pm 0.04 \mathrm{~b}$ & $21.148 \pm 0.01 \mathrm{a}$ & $19.463 \pm 0.02 \mathrm{c}$ \\
$r_{m}$ & $01763 \pm 0.001 \mathrm{a}$ & $01672 \pm 0.001 \mathrm{~b}$ & $01719 \pm 0.002 \mathrm{a}$ \\
$\lambda$ & $11928 \pm 0.006 \mathrm{a}$ & $11,820 \pm 0.004 \mathrm{~b}$ & $11,876 \pm 0.007 \mathrm{~b}$ \\
\hline
\end{tabular}

Means within a row followed by the same letter do not differ significantly (Tukey's test: $P>0.05$ )

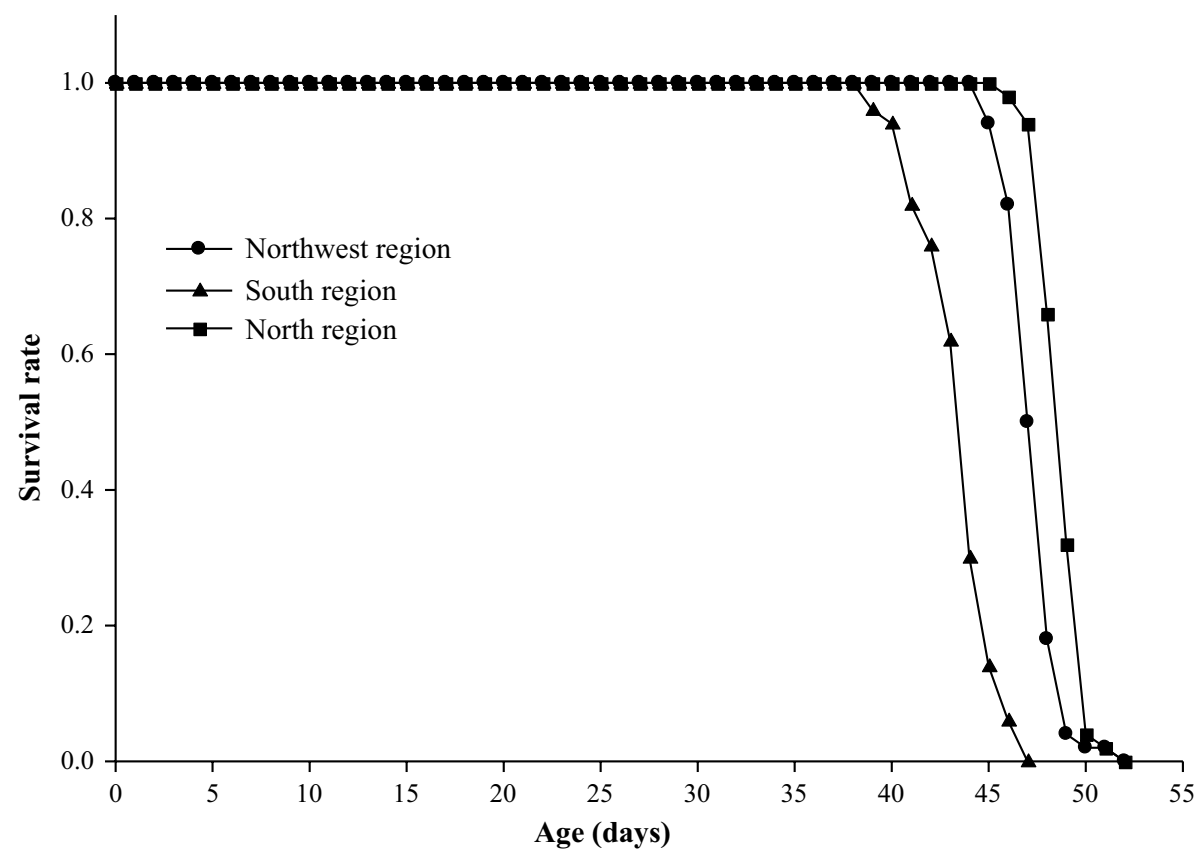

Fig. 1 Survival rate of Brevipalpus yothersi collected in the northern, northwestern and southern region of Sao Paolo state, Brazil, maintained at $23 \pm 1{ }^{\circ} \mathrm{C}, 60 \pm 10 \% \mathrm{RH}$ and $14 \mathrm{~h}$ of daily photoperiod

\section{Discussion}

Values of the biological parameters were similar to those previously determined by other authors for populations identified as B. phoenicis. A Brazilian population reared by Chiavegato (1986) on citrus fruits at $25 \pm 1{ }^{\circ} \mathrm{C}, 70 \pm 10 \% \mathrm{RH}$ and $12 \mathrm{~h}$ daily photoperiod had a life cycle of 19.2 days, longevity of 22.2 days and average fecundity of 22.5 eggs per female. Under similar environmental conditions, Haramoto (1966) determined that immature development required longer to be completed on papaya (29.3 days), suggesting that the substrate had a pronounced influence on mite development. 
Zaher et al. (1971), Chiavegato (1986) and Trindade and Chiavegato (1994) showed the reduced duration of the immature phase with increasing temperature, as universally known for invertebrates. Souza (2002) evaluated the effect of relative humidity on B. phoenicis (probably B. yothersi). This author verified that extreme values (30 and 90\% RH) interfere negatively in the biological development of B. phoenicis, whereas $60 \% \mathrm{RH}$ was most favorable. The $30 \% \mathrm{RH}$ affected eggs viability, with egg hatching rate ranging from $32.2 \%$ (at $30 \% \mathrm{RH}$ ) compared to rates of 91.0 and $92.2 \%$ at 60 and $90 \% \mathrm{RH}$, respectively.

Winter is drier in northern and northwestern São Paulo State than in the southern region of the state (INMET 2015), favoring the development of B. yothersi (Oliveira 1986; Silva et al. 2012). Laranjeira et al. (2015) reported that the combination of longer days, higher temperatures, lower relative humidity and lower evapotranspiration levels increase the likelihood of B. phoenicis infestation. The water content in the soil has also been assumed to affect the population growth of Brevipalpus spp. Andrade et al. (2013) found that populations of Brevipalpus spp. developed faster on citrus plants under water stress (field capacity below 55\%), with a consequent increase in citrus leprosis severity.

For species of the $B$. phoenicis group, life-table parameters have only been reported for three Brazilian populations, all identified as $B$. phoenicis. The value of $R_{o}$ obtained in this study was slightly higher than that reported by Medeiros (2002) on jack bean leaves (Canavalia ensiformes [L.] DC.; Fabaceae) $\left(R_{o}=18.1\right)$, and intermediate to those reported by Alves (1999) on citrus (12.8 and 26.8 times per generation).

The results of the present study indicated that the different measures adopted in the control of the three populations did not lead to major biological differences between populations for the evaluated parameters, rejecting our initial hypothesis. Hence, it seems that the lower population levels of B. phoenicis (probably B. yothersi) reported by Bassanezi et al. (2002) in the southern region of São Paulo State can be attributed to the slightly lower average temperature and higher rainfall compared to other regions, and not to different biological characteristics of the populations. This assumption is also supported by the great similarity of the three populations in relation to life-table parameters.

An alternative or addition reason may be the less intensive citrus cultivation in the southern region, where groves occupy a smaller proportion of the area, being usually surrounded by other crops, mainly sugarcane, Saccharum officinarum L., and natural vegetation. This situation may determine reduced availability of virus inoculum and viruliferous mites. Still another possibility could be the variation between populations in the ability to transmit the virus.

It is important to mention that in the northern and northwestern regions there are differences in the occurrence and severity of other pests and diseases resulting in the use and quantity of various pesticides compared to southern region (Bassanezi et al. 2014). It is known that pesticides cause biological, genetic and behavioral changes in mites (PascualRuiz et al. 2014; Guedes and Cutler 2014), moreover affect their natural enemies or even cause modifications in the physiology of the host plant (Guedes and Cutler 2014), possibly changing their susceptibility to mites and CiLV virus.

Differences regarding the adaptation of $B$. yothersi to a host type also cannot be neglected to explain the incidence of citrus leprosis. Adapting to specific hosts often involves trade-offs that limit performance on other hosts (Fellous et al. 2014). Fellous et al. (2014) concluded that the polyphagous mite Tetranychus urticae Koch (Acari: Tetranychidae) can adapt in a few generations to a new host, but at the expense of decreased performance on other hosts. Thus, studies to evaluate those alternative hypotheses seem warranted, in an attempt to determine the reason for the lower incidence of citrus leprosis in the southern region of São Paulo State. 
Acknowledgements The authors thank the Coordination of Higher Education Personnel ImprovementCAPES, for first author's scholarship; Dr. Alessandra Marieli Vacari, for helping in statistics; Marcio Augusto Soares, for providing mite samples from the Agroterenas farm; and the owners of Vila Rica and Costa e Melo farms, also by providing with mite samples. Our gratitude also extends to Dr. Jeferson Luiz de Carvalho Mineiro for the assistance in identifying the Brevipalpus species.

\section{References}

Akkopru EP, Atlihan R, Okut H, Chi H (2015) Demographic assessment of plant cultivar resistance to insect pests: a case study of the dusky-veined walnut aphid (Hemiptera: Callaphididae) on five walnut cultivars. J Econ Entomol 108:378-387

Alves EB (1999) Manejo da resistência do ácaro-da-leprose Brevipalpus phoenicis (Geijskes, 1939) (Acari: Tenuipalpidae) ao acaricida Dicofol. Dissertação, Universidade de São Paulo

Andrade DJ, Falconi RS, Siqueira DS, Barbosa CL, Ferraudo AS, Oliveira CAL (2013) The influence of citrus rootstocks on the relationship between the mite Brevipalpus phoenicis and citrus leprosis disease. Pest Manag Sci 69:81-87

Bassanezi RB, Spósito MB, Yamamoto PT (2002) Adeus à leprose. Cultivar 2:6-8

Bassanezi RB, Ayres AJ, Massari CA, Belasque Junior J, Barbosa JC (2014) Progressão e distribuição espacial das principais pragas dos citros. In: Andrade DJ, Ferreira MC, Martinelli NM (eds) Aspectos da fitossanidade em citros. Cultura Acadêmica, Jaboticabal, pp 31-50

Bastianel M, Novelli VM, Kitajima EW, Kubo KS, Bassanezi RB, Machado MA, Freitas-Astúa J (2010) Citrus leprosis: centennial of an unusual mite virus pathosystem. Plant Dis 94:284-292

Beard JJ, Ochoa R, Braswell WE, Bauchan GR (2015) Brevipalpus phoenicis(Geijskes) species complex (Acari: Tenuipalpidae)—a closer look. Zootaxa 3944:1-67

Chi H (1988) Life table analysis incorporating both sexes and variable development rates among individuals. Environ Entomol 17:26-34

Chi H (2016) TWOSEX-MSChart: a computer program for the age-stage, two-sex life table analysis. http://140.120.197.173/ecology/Download/TWOSEX-MSChart.rar. Accessed 25 May 2016

Chi H, Liu H (1985) Two new methods for the study of insect population ecology. Bull Inst Zool 24:225-240

Chi H, Su HY (2006) Age-stage, two-sex life tables of Aphidius gifuensis(Ashmead) (Hymenoptera: Braconidae) and its host Myzus persicae (Sulzer) (Homoptera: Aphididae) with mathematical proof of the relationship between female fecundity and the net reproductive rate. Environ Entomol 35:10-21

Chiavegato LG (1986) Biologia do ácaro Brevipalpus phoenicis em citros. Pesq Agro Bra 21:13-16

Efron B, Tibshirani RJ (1993) An introduction to the bootstrap. Chapman and Hall, New York

Fellous S, Angot G, Orsucci M, Migeon A, Auger P, Olivieri I, Navajas M (2014) Combining experimental evolution and field population assays to study the evolution of host range breadth. J Evol Biol 27:911-919

Guedes RNC, Cutler GC (2014) Insecticide- induced hormesis and arthropod pest management. Pest Manag Sci 70:690-697

Haramoto FH (1966) Biology and control of Brevipalpus phoenicis (Geijskes) (Acarina: Tenuipalpidae). Hawaii Agricultural Experiment Statation, Honolulu

Huang YB, Chi H (2012) Age-stage, two-sex life tables of Bactrocera cucurbitae (Coquillett) (Diptera: Tephritidae) with a discussion on the problem of applying female age-specific life tables to insect populations. Insect Sci 19:263-273

INMET - Instituto Nacional de Meteorologia (2015) Disponível em: <www.inmet.gov.br/> Acesso em: 08 novembro 2015

Laranjeira FF, Silva SXB, Andrade EC, Almeida DO, Silva TSM, Soares ACF, Freitas-Astuá J (2015) Infestation dynamics of Brevipalpus phoenicis (Geijskes) (Acari: Tenuipalpidae) in citrus orchards as affected by edaphic and climatic variables. Exp Appl Acarol 66:491-508

Medeiros MB (2002) Ação de biofertilizantes líquidos sobre a bioecologia do ácaro Brevipalpus phoenicis. Tese, Universidade de São Paulo

Mineiro JLC, Sato ME, Novelli VM, Andrade DJ (2015) Distribuição de Brevipalpus yothersi Baker, 1949 (Acari: Tenuipalpidae) em diferentes hospedeiras e localidades no estado de São Paulo. 28a Reunião Anual do Instituto Biológico, São Paulo

Oliveira CAL (1986) Flutuação populacional e medidas de controle do ácaro Brevipalpus phoenicis em citros. Laranja 6:1-32 
Pascual-Ruiz S, Gomez-Martinez MA, Ansaloni T, Segarra-Moragues JG, Sabater-Munoz B, Jacas JA (2014) Genetic structure of a phytophagous mite species affected by crop practices: the case of Tetranychus urticae in clementine mandarins. Exp Appl Acarol 62:477-498

Roy A, Hartung JS, Schneider WL, Shao J, León MG, Melzer MJ, Beard JJ, Otero-Colina G, Bauchan GR, Ochoa R, Brlansky RH (2015) Role bending: complex relationships between viruses, hosts and vectors related to citrus leprosis, an emerging disease. Phytopathol 105:1013-1025

Salinas-Vargas D, Santillán-Galicia MT, Guzmán-Franco AW, Hernández-López A, Ortega-Arenas LD, Mora-Aguilera G (2016) Analysis of genetic variation in Brevipalpus yothersi (Acari: Tenuipalpidae) populations from four species of citrus host plants. PLoS ONE 11(10):e0164552

Silva SXB, Laranjeira FF, Andrade EC, Almeida DO (2012) Dinâmica da infestação de Brevipalpus phoenicis (Geijskes, 1939) (Acari: Tenuipalpidae) em pomares cítricos da Bahia, Brasil. Rev Bras de Frutic $34: 77-83$

Souza RS (2002) Aspectos da inter-relação: Ácaro da leprose Brevipalpus phoenicis (Geijskes, 1939) (Acari: Tenuipalpidae), Citrus sinensis (L.) e meio ambiente. Dissertação (Mestrado em Agronomia) Faculdade de Ciências Agrárias e Veterinárias, Universidade Estadual Paulista

Trindade MLB, Chiavegato LG (1994) Caracterizacao biológica dos ácaros Brevipalpus obovatus D., B. californicus B. e B. phoenicis G. (Acari: Tenuipalpidae). An Soc Entomol Bras 23(2):189-195

Zaher MA, Wafa AK, Yousef AA (1971) Biology of Brevipalpus phoenicis (Geijskes), in Egypt (Acarina:Tenuipalpidae). Bull Soc Entomol d'Egypte 54:177-183 